\title{
Alienation and Emotion: Social Relations and Estrangement in Contemporary Capitalism
}

Ian Burkitt

University of Bradford

This is the post-acceptance version of an article appearing in the journal Emotions and Society and must not be cited.

\section{Abstract:}

In this article I look at the emotional effects of alienation in modern capitalist societies. I begin by considering Marx's theory of alienation, focusing especially on the alienation between people and between them and the social institutions to which they should be connected. In this way, alienation is understood as a form of estrangement within social relations and I draw out the emotional implications of this, in terms of the relations between people and in the way people feel about their own self. This is enhanced through an understanding of emotions as relational phenomena, a position highly attuned to Marx's own mode of social analysis. I then illustrate and develop this understanding of alienation and emotion by drawing on the empirical examples of political relations and property relations in the UK, concluding with a discussion of what this tells us about alienation and emotion in contemporary capitalist societies.

\section{Key words:}

Alienation; emotion; estrangement; social relations; politics 


\section{Alienation and Emotion: Social Relations and Estrangement in Contemporary Capitalism}

There is a rich seam of literature in social science and philosophy on alienation and emotion, but this tends towards the view that alienation creates emotional numbness or a condition in which we fail to connect with our emotions properly, thus experiencing inauthentic emotion. In key work in the social sciences this has been seen as the result of the commercialisation of emotion in the workplace (Hochschild, 1983; Brewer, 2011) and in philosophy as the outcome of general processes of emotional self-alienation (Szanto, 2017). I want to take a different approach to alienation and the emotions in this article, arguing that alienation does not always result in a loss of connection to our emotions or their sense of authenticity. Instead, I will make the case that alienated social relations produce strong emotions that result from those relations, telling us something about what is going on in our societies. In doing this I want to build on Marx's theory of alienation, drawing out its implications for emotion. This creates a different approach to emotion within capitalism to that which Illouz (2007) has called 'emotional capitalism'. In her approach, emotional and economic discourses and practices mutually shape each other, so that affect becomes an essential aspect of economic behaviour, while emotional life is shaped by economic relations and by markets. Although this work is important and highly illuminating, it does tend to focus on how this broad process of emotionalising capitalism has affected middle class women and men in the workplace and the family, overlooking class conflict and inequality, as well as touching only lightly on alienation. 
In what follows I will address this by concentrating on the issue of alienation and emotion in aspects of a contemporary capitalist society like the UK. In the first section here I will focus on Marx's theory of alienation, particularly in terms of the alienation of humans from one another and from key forms of social organisation in capitalism, such as the state and the realm of politics, drawing out the implications of this for emotions. In the second section I will briefly elaborate the theoretical move to understand emotions as relational phenomena, something that I believe ties in closely with Marx's relational view of social science. Then in the third section I will illustrate and develop the understanding of alienation and emotion by drawing on empirical examples centred on recent political events in the UK and in property relations. I then discuss the implications of these examples for our understanding of emotions in contemporary capitalism.

\section{Marx and alienation}

In Marx's thinking, alienation is one of the results of capitalist social relations and it occurs when the things that human beings produce come to stand against them as something alien - that is, as objects in which they recognise nothing of themselves or of their own productive activity (Marx, 1977). This happens in capitalism because workers do not own the objects they produce and also because, in highly specialised divisions of labour (created in the drive for profitability), workers may not see the end product of their work activity, nor feel any connection to it. Under such conditions, commodities appear on the 
market as if by magic, because we do not feel any connection to the labour activity that has produced them, either our own or that of others. We are then sold products that become, if we can afford to buy them, individual possessions that have no connection to the wider social whole that has produced them. However, alienation has greater ramifications than this for human beings. Because Marx understood humans as a species that enter into social relations in order to produce the means of subsistence, which is a unique characteristic of human beings, in losing contact with the object of production we also lose contact with our own nature as species-beings. And because production is essentially a social activity, we also lose touch with each other in the collective effort of production. In production, the capitalist (or the manager or boss) is a representative of that class and stands over and against the workers as a hostile power, organising and disciplining labour purely in the pursuit of profit and greater efficiency. The workers too are often forced to compete against one another, either as individuals or in teams, to boost productivity and thus come to see themselves as isolated individuals pursuing their own interests. As Ollman (1971) puts it, for Marx an alienated person is ‘separated from his fellow men (competition and class hostility have rendered most forms of cooperation impossible)' (p. 134). Additionally, workers can become distanced from their own activity, especially if they are working purely in order to earn a wage and have no other personal investment or interest in the job they are doing.

In summary, then, it can be said that for Marx alienation occurs in the relation of humans; 1 ) to the things we produce, 2) to our own nature as humans or speciesbeings, 3) to each other, and 4) to our own activity (Marx, 1977; Ollman, 1971). It 
is the third aspect of alienation that I will focus on here, the alienation of humans in their relations to one another and to their own self - these two relations being inextricably bound together - and the emotional effects of this. Suffice to say for now that it should be clear from what has gone before that alienation is a condition bound up with social relations. Indeed, as Ollman (1971) points out, all the units in Marx's analysis, including society, are understood relationally, so that 'Capital, labour, value, commodity, etc., are all grasped as relations, containing in themselves, as integral elements of what they are, those parts of which we tend to see them externally tied' (p. 15). Thus, relations in Marx are conceived of not as external relations - that is, the relation between things that would remain the same in their essence even if the relations between them changed - but instead as internal relations. This means that, in Marx's view, relations are internal to each factor in his analysis because they are ontological it is the relation between things that gives each one its essence, rather than some pre-given essence that inheres within it, a priori.

Alienation is therefore also to be conceived of relationally. As Jaeggi (2014) puts it, alienation is a relation of relationlessness: not in the sense of the absence of a relation but rather of a relation that is in some way deficient. There is a detachment or separation between people or things that in fact belong together, 'the loss of a connection between two things that nevertheless stand in relation to one another' (Jaeggi, 2014, p. 25). For Marx, alienation is also referred to as 'a mistake, a defect, which ought not to be' and as the 'realm of estrangement' (Ollman, 1971, p. 132). This is really important and I will continue to refer to alienation as estrangement, because it is a deficient, broken relation - a 
separation between people, or between people and things, that are, or ought to be, related. To be a stranger is to be unknown in a particular place or community, as in 'I was a stranger in the city'. But to be estranged is to be known and have a prior relationship only for it to be damaged ('I am now estranged from my family') or for it to be deficient ('I am estranged from my father, we've always had a difficult relationship'). However, for Marx, alienation is both more specific and more widespread than this, because it is ingrained in the nature of capitalist social relations where, as was noted above, there is a break or separation between people, both within and between social classes. Here, the alienated person is an 'abstraction' - a term Marx used to refer to any factor which appears isolated from the social whole of which it is a part, thus losing its sense and meaning. Society also becomes a 'fixed abstraction' opposed to the individual (Marx, 1977, p. 91), in that although society only exists because it is produced and reproduced through the activities of individuals who stand in relation to one another, it nevertheless comes to feel as though it is an alien or coercive power separated from us, over which we have little power or influence to change it. Thus, an...

...alienated world presents itself to individuals as insignificant and meaningless, as rigidified or impoverished, as a world that is not one's own, which is to say, a world in which one is not 'at home' and over which one can have no influence (Jaeggi, 2014, p. 3). 
Despite the fact that humans are social beings, through alienated relations we come to feel as though the society we jointly create stands above us as an alien power, and that our fellow humans are, like our own self, primarily isolated individuals with deficient social relations to connect us (except, perhaps, for particular relationships in which we feel close and connected to others). It is not, therefore, only objects of production that people create and yet come to feel alienated from: this can also happen with respect to social forms, such as organisations, institutions, governments, political parties, etc. As Ollman (1971) puts it, 'parliaments, laws and the rest have assumed the guise of quasi-supreme beings to which their own creators are asked to pay obedience' (p. 216).

Alongside this, and in becoming alienated from each other and from social institutions, people can also be alienated in the relation to their own self. Marx (1977) says that the 'alienation of man and in general of every relationship in which man stands to himself is first realised and expressed in the relationship with which man stands to other men' (p. 83). Thus, the way we come to see our own self is the result of these deficient relationships in which we only recognise our self and others through the qualities that accrue to each of us in our class position. People react to one another as a 'kind' or 'type' or 'role', and only indirectly to the individual as a reflection of it, to their all-round uniqueness as a person. The Marxist literary theorist, Mikhail Bakhtin, gives a good example of this from a scene in Dostoevsky's novel Poor Folk, in which a poor man overhears someone say that the most important virtue in a citizen is to earn money and not be a burden on society. In an internal dialogue with himself, the poor man answers the stranger back, saying to himself that - 'I'm not a burden to anyone. 
My crust of bread is my own...earned by my toil and put to lawful and irreproachable use' (Dostoevsky in Bakhtin, 1984, p. 207).

In a scene such as this, reminiscent of the kind of interactions that happen in everyday life, referring to social categories - a 'poor person' or a 'good citizen' entails a whole host of moral evaluations, such as the poor do not earn money and are a burden on society. This entails what Bakhtin (1984) calls an 'emotional-evaluative' stance, in that seeing someone as of more or less worth makes them feel something, like a sense of pride and self-worth or shame and a sense of low-worth. We can see this in the response of the poor man in his own internal dialogue, who clearly feels that the overheard comment could reflect negatively on him: feeling degraded and ashamed he answers back that although he doesn't earn much money, he does so by his own toil and can feed and care for himself, therefore making himself feel proud of his efforts. His comment about putting his earnings to lawful and irreproachable use is also his way of saying 'I am a good citizen' and to make himself feel worthy in what he does. This is an example of what Marx said above, about how the alienation of every relationship in which a person stands to them self is first realised and expressed in the relationships with which a person stands to others. What the example of the poor man shows, though, is that these relationships also have emotional dimensions through the emotional-evaluative stances taken towards others and towards one's self.

It is important to note, though, that the emotional injuries of misrecognition is not just a matter of being looked down on but, as Holmes and McKenzie (2018) point out, being denied the status of a full partner in interaction and prevented 
from participating in social life as a peer. Furthermore, I would add that it is not just in interpersonal relationships that alienation and its emotional dimension is revealed. It can also be revealed in those social institutions that come to stand over and against us as alien, powerful and dominating forces. For Marx, as for Hegel before him, human individuality is a social achievement in that each person only individuates them self within the social whole. As Marxists see it, each person appropriates the human heritage - which is created through human activity in the course of history - through their activities in society, realising their own powers and developing capacities to act in particular ways: say, in becoming a scientist or an artist, making their own contribution to the furtherance of culture. Appropriation therefore occurs actively as we build elements of the human heritage into our own character as capacities, expressing these in our own particular way. According to Hegel, we also realise the particularity of the self in the ethical universality of human society, so that alienation represents a deficiency in the relation of self to the social whole (Jaeggi, 2014). This reflects in institutions that stand in opposition to us rather than being ones in which we can recognise ourselves, identifying with them and realising our ethical powers in relation to them - such as the law, government, politics, or civic life. Here, what G. H. Mead (1934) called the 'generalised other' the organised collective attitudes in society embodied in social institutions such as law, politics, or religion - feels as though it opposes us in our own consciousness, our own internalised dialogue, perhaps condemning us in the way the poor man in Dostoevsky's novel felt condemned. This can occur in social ideologies or attitudes that denigrate specific social groups - the 'feckless poor', the 'idle rich', the criminalised racial minority, etc. As I will show throughout the 
rest of this piece, these kinds of alienated relationships also have emotional dimensions to them.

Before I move on to the topic of emotions, there is one final point I want to make about alienation. That is, not all relationships and activities within capitalist societies are alienated to the same degree. Some relationships and activities are less alienated than others, giving us scope to realise our human powers and capacities. For example, as the French Marxist Lucien Sève (1978) claimed, there are many relationships and activities across the range of our biographies in which we can realise our potentials, learn new capacities, and create individual identities. This is influenced by social class, in that the middle class may have greater access to more fulfilling professions, in which there is more scope to learn new skills and, thus, for self-development and the sense of higher selfesteem. Yet everyone has some aspect of their lives that are not alienated, where their relationships and activities are less deficient, otherwise it would be impossible to recognise alienation as a condition - that is, to know that certain relationships are deficient. Alienation is not, then, - certainly not in the tradition of Hegel and Marx - a universal condition of the individual in society, as in some existential forms of thought, nor is alienation universal and evenly distributed across capitalist societies. Even here, there are some relationships in which we feel as though others know and value us as a person rather than as a category or type: they see us in the round as opposed to seeing only one side of us, leading to greater emotional fulfilment. 


\section{Emotions in relationships}

In a similar way to the units in Marx's analysis, which are seen to be formed relationally rather than as units that existed prior to the relations that connect them, those who theorise emotions as relationships do not conceive of emotions as something given in themselves - such as biologically fixed bodily responses to external stimuli that appear the same everywhere, across all human societies, whenever those stimuli appear. Instead of this, emotions are to be understood as bodily feelings that are formed within the social relations and activities that give them meaning and value (Burkitt, 2014). Emotions, then, are part of human activity and are experiences that emerge out of specific situations in which we are related to other people and things in a socially meaningful way. Thus, although emotions are associated with certain bodily feelings and with our reflexive consciousness of them as experiences we can verbalise and reflect on, these would not make sense without the specific relational situation in which they have emerged. This means that when we think of emotions we should not conceive of them primarily as things belonging to us as individuals - like the feeling called 'love' or 'anger' - but rather as patterns of relationship we are woven into and which form our interconnection with other people and things. 'Love', then, is an indication about the people and things we value the most and also about the relation of those people and things to us - a love lost, a new love found, or a love that is unrequited. Emotions are relational in that they always inform us about the relationships we have to other people and things.

The relational approach to emotions, then, is close to Emirbayer's (1997) model of relational sociology, in that the social world is not understood as primarily 
consisting in substances or things. Instead, the relational perspective understands the units of enquiry (such as emotions) to derive their meaning, significance, and identity from their emergence in social relations. Following from this, for me, emotions are to be understood as produced in the activities of people who stand in relation to one another, so that emotions always carry implicit or explicit meaning and value, which is both social and personal, orienting us in the social world. In the case of alienation, though, given that these relations are ones of estrangement and are deficient, perhaps we should say that to some degree they disorientate us, reflecting our distorted relations to others. This was illustrated in the case of the 'poor man' from Dostoevsky's novel, recounted above, where this man felt himself looked down on by those higher up the social order because he was poor and excluded from full participation in social action as a complete citizen. This relation led to an emotional-evaluative stance in which the poor man felt degraded and belittled, but it also motivated him to counteract these feelings with words of his own about himself that made him feel proud and worthwhile. His emotions are relational in that his feelings would not make sense outside of the situation in which he overheard a derogatory remake about the poor: however, they are also ideological in that they involve socially meaningful attitudes adopted towards people within the relational network of a social hierarchy. In dominant ideologies, the wealthy and powerful are accorded a higher status and social value than those below them, along with greater powers to act. Relations and ideologies therefore create evaluations that are integral to emotions - the feelings we have about others and, through them, about our own self as well. 


\section{Alienation and emotion in politics and property relations}

In this section I will elaborate on the theory of alienation between people - and between people and institutions - by looking at recent studies of politics and emotions in the UK. Here, I focus on the attitudes of working class people towards political parties and the way they voted in the 2010 and 2015 general elections and in the 2016 referendum on the UK's membership of the European Union (EU). I also focus on the alienated nature of property relations in the modern, rapidly gentrifying city. Under the subheadings below, I draw on Holmes and Manning's studies of working class voters in the North of England leading up to the 2010 general election (Holmes and Manning, 2013; Manning and Holmes, 2013) and on Mckenzie's (2017a; 2017b) ethnographic studies of working class communities in East London and the East Midlands during the 2015 general election and the referendum on EU membership in 2016. Although these authors do not refer to alienation in their studies, I think the effects of this, and its links to emotions, can be seen in the results of their ethnographic work. I will also supplement this with some examples of newspaper reporting of the views of people caught up in the Grenfell Tower fire disaster in North Kensington, West London, on $14^{\text {th }}$ June 2017. Together, I feel these examples allow me to demonstrate important aspects of alienation and emotions in regard to two separate issues: first, in respect of politics and political relations in the UK in recent years, and second with regard to property relations and the

relationship of communities to their local authority and the national government (indeed, to 'authorities' more generally). These examples allow me to put some 
flesh onto the bones of the theoretical consideration of alienation and emotion in the first two sections of this article and also to develop this theory.

\section{Alienation and emotion in politics}

During the 2000s the steady decline in people voting in UK elections, especially in poorer areas of the country and among the young, was attributed in popular discourse to a growing apathy among these groups in regard to political participation. This is challenged in the work of Holmes and Manning who did qualitative interviews with voters in working class areas of Yorkshire and the North West of England in the run-up to the 2010 general election. They recruited participants for their interviews in areas where there had been a decline in the turnout at the European elections in 2004 and 2009, which had allowed the farright British National Party (BNP) a greater percentage of the vote. All their participants were white in terms of their ethnicity and were working class, in that they all did low-paid unskilled or semi-skilled work, although none had actually voted for the BNP. Instead, they all voiced a cynical disengagement with mainstream politics and political parties, although Holmes and Manning's findings show this does not mean they were apathetic, as all participants had opinions and feelings about politics and the deprivation they were facing.

What was common among their participants was the expressed feeling of being 'fed-up' with the current political and economic status quo and having little expectation that the upcoming 2010 general election would bring any significant beneficial change for them, no matter which political party won (Holmes and 
Manning, 2013). Because of this they were disengaged rather than apathetic about politics, seeing politicians as too distant from them and their own everyday, local concerns. This distance seemed to take two main forms. First, politicians were seen as coming from wealthy elites and so were unable to understand the daily struggles of people on low wages, living in communities blighted by social and economic disadvantage. This was expressed by one person who remarked of the Conservative Party leader at the time, David Cameron, 'he's snooty 'im' (Manning and Holmes, 2013, p. 483). Second, the sense of distance was manifested as politicians being located in Westminster in the heart of London and so unfamiliar with the poverty and decline of the deindustrialised areas of the North of England. Politicians were seen as 'far away' from the living conditions of working class people and the problems of local areas, and politics in general was too 'top-down' to be relevant to local concerns (Holmes and Manning, 2013, p. 488). Although the people in this study had no sympathy with the overtly racist policies of the BNP, they did express dissatisfaction with the Labour Party - that once had represented the interests of the working class feeling frustrated that it had adopted policies too close to those of the Conservative's. One person remarked that Tony Blair's idea of 'New Labour' showed 'no commitment to social to what socialism or nationalisation, which meant they're fairly middle of the road really' (in Holmes and Manning, 2013, p. 487). Overall people in the study felt disengaged from mainstream politics, were angry about the recent Member of Parliament's expenses scandal - where the media had found evidence of some MP's abusing expense claims - and were frustrated with a political elite who seemed out of touch with the hardships faced by working class voters. 
In a similar vein, Mckenzie's (2017a) work shows a widening distance between marginalised working class voters and the established political parties. She interviewed groups of working class men and women in East London during the 2015 general election campaign and found growing dissatisfaction with the main parties. For example, one woman, Anne, who would normally vote for the Labour Party, said she wasn't going to bother voting because she didn't like the then Labour leader (Ed Miliband) and because national politics didn't reflect local concerns about schools, housing and the state of the health service. When asked if not voting might make these things worse, with all the cuts to public spending coming down the line, she replied 'Worse than what? Worse than now?! I'm not sure it can get any worse can it?' (in Mckenzie, 2017a, p. 203). In the group of men Mckenzie interviewed most said that if they were going to vote they would vote for UKIP (the UK Independence Party who campaigned on issues of immigration and leaving the EU), although most admitted after the election that they hadn't voted at all. The reason for this was similar to the women, in that they felt excluded from political decision-making over things that were affecting them locally, in particular the precarious nature of their employment and lack of a good, steady income. In general, people didn't vote because they 'did not see a direct connection between themselves, their political and social position and the general election' (Mckenzie, 2017a, p.204).

In contrast to this, these same people felt energized and enthusiastic about voting in the European referendum. In the group of women Mckenzie was researching, the same woman mentioned above, Anne, was encouraging her friends to register to vote, then to vote to leave the EU. During the referendum 
campaign the women also responded angrily to experts and the rich and famous who were advising people to vote to remain in the EU. Responding to a report that the footballer David Beckham was apparently advising people to vote Remain, the women gave vent to their anger, referring to their main issues about schools and housing:

Anne: 'That fucking David Beckham can fuck right off, telling people to vote Remain'

Sarah: 'What does he know about anything? When has he had to struggle to get his kids into school?'

Sally: 'Yeah, him and Posh got no housing problems, apart from which one are they going to live in!' (in Mckenzie, 2017a, p. 205).

For me, the above is an interesting vignette, because it shows that the women, in their reasoning and their emotions, are acutely attuned to their situation - a lack of good school places in their area and a lack of affordable housing - and their relationship to the rich and famous, for whom these things are not a problem. There is an estrangement in the relation between the social classes, especially with the political class, and a sense of unfairness, injustice and exclusion. There is also a lack of mutual recognition and understanding expressed in the prior disengagement with the 2015 election campaign and now the excitement and anger of the 2016 referendum, with many believing the established parties are no longer listening to them or representing their interests. After the Leave result 
in the referendum some of the women were overjoyed. However, others said that they did not think things would be better for them out of the EU but that they thought things couldn't get worse or that they couldn't stand things being the same (Mckenzie, 2017a).

In contrast to the anger, frustration and disconnection that Mckenzie encountered in East London, in the ex-mining communities of Nottinghamshire and Derbyshire in the East Midlands of England studied after the referendum, she found feelings of sadness, loss and fear, despite the fact many had voted Leave. These towns had suffered deindustrialisation with the loss of jobs in mining and manufacturing since the 1980s, such jobs being replaced in the 2000s by employment in warehouses and distribution centres that create work which is, in comparison, low-skilled and poorly paid. In this region, Mckenzie (2017b) spoke to two groups of women who had worked in the clothing manufacturing industry and two groups of men who had been miners. The people in these groups felt abandoned by traditional British political parties, felt the loss of self-respect and status that skilled jobs in once key British industries had brought them, along with fear about the break-up of their communities and the loss of younger family members moving away from the area to find work.

Although Mckenzie, as well as Holmes and Manning, do not mention alienation in their research, I feel that the concept of alienation can add an extra dimension to the interpretation of their findings. I would argue that the distance, disengagement, and abandonment people feel with respect to politicians and political parties is an expression of the estrangement typical of alienation - of a broken or deficient relation that people feel between themselves and the 
established political parities. This is so especially in relation to the Labour Party that at one time sought to represent the interests of the British working class. In addition, the hostility that many working class voters showed to the EU in the 2016 referendum displays estrangement from the political system at an international level. Alienation is therefore evident in the relation between people and the political system, including all the institutions that compose it - local, national, and international governments, along with the political parties that make the democratic system of government work. People felt abandoned by the political class and that the established political parties no longer represented their local concerns, such as the state of schools, housing and employment. All of this perhaps explains the fall in membership of political parties across Europe, and the fact that parities now seek to present themselves as responsible economic managers, particularly to financial markets, but are not responsive to voters or representative of particular class identities (Mair, 2013). From the point of view of my interest here, these alienated relations work themselves out differently in the social contexts and situations where they are found, creating the emotions of dissatisfaction and anger, or sadness, loss and fear.

In these emotions we see what E. P. Thompson (1980) called a structure of feeling - a pattern of emotions felt by members of a social class in response to commonly experienced and emergent economic and social conditions. Similar to the structure of feeling Thompson noted among working class people in the early 1800 s, we see in the studies above the loss of self-respect and status among the working class that results from losing well paid and skilled jobs in prestige industries, and the fear of losing family and community - social networks that 
provided a source of identity, mutual support and solidarity for working people. Many of those in Mckenzie's study were also mortified at the way people like themselves - working class people who had voted Leave - were represented in the Remain camp after the referendum, as being racist, uneducated and not knowing what they voted for. Their concerns about immigration were to do with its effects on pay, jobs, and increased pressures on already stretched social services, getting worse due to the austerity cuts in public spending after the financial crash of 2008. The alienation of social relations reflects in this loss of mutual recognition and the resulting misunderstanding and misrepresentation of people in different social classes, the relations between which are increasingly estranged, deficient, and broken by growing inequalities.

\section{Alienation and emotion in property relations and in relation to authorities}

A key concern of many working class residents of London is the trend that has become known in the UK as 'social cleansing'. This term refers to the suspected attempt of local authorities and property developers to move traditional residents out of certain areas of London and, with property prices so high, to sell off the land where working class residents live - often in council owned and rented properties or in social housing owned and rented by housing association charities - to build properties for sale or rent at much higher prices. This is a concern of 'Peter', one of the participants in Mckenzie's (2017b) study, a 66 yearold retired street cleaner who has always lived in the East End of London. In fact, Peter lives in one of the few remaining blocks of housing association flats in his 
area, where he still likes to walk the streets everyday just as he did when he was cleaning them. On a day when Mckenzie accompanied him on his walk, Peter was complaining about the 'Yuppie drones' invading the area, with shiny new apartment blocks and suites of offices being built everywhere around him. He says he doubts that he will survive this invasion and that he feels like he lives on a 'reservation'. Looking in a showroom for a block of flats, the workers there seem annoyed that Peter is staring at them and wave him off, with Peter responding by sticking two fingers up at them in an angry gesture and telling them to 'fuck off'. A security guard comes out and follows Mckenzie and Peter as they walk off down the road, with Peter turning and giving the two-finger salute to him as well. Further on they come across a father and his three children, the kids playing in the water feature of another new development in the area. Again, a security guard appears to move the family on with the father shouting, 'Where are we supposed to go, my kids have got nothing', to which the guard responds, 'You do not belong here, this is not for you' (in Mckenzie, 2017b, p. S273).

For me this is an example of alienated relations and the emotions expressed here reflect that. For Peter, the wealthier office workers and residents moving into the area are 'Yuppie drones', an alien invasion driving out older working class residents like him self. His expressions of anger at them are a reflection of his sense of estrangement from them, and likewise they see him as a nuisance to be moved on. The security guards moving residents off these private properties are working people, not dissimilar in their social class and status from Peter or the young family, the father of which said his kids had nothing. However, in their role as security guards for private property, both Peter and the young family 
were seen as loitering in a place where they didn't belong, a place that is 'not for you'. The irritation and hostility in this comment represents the security guard's attitude to those he sees as loitering, but Peter and the young family have nowhere else to go. All the participants in these interactions are responding to each other as types instead of as fully rounded characters: Peter to the 'Yuppie drones'; the office workers and security guards to local residents they see as loiterers who are out of place and shouldn't be there. Given this these alienated interactions are coloured with anger and hostility. When Mckenzie asked Peter about his participation in recent elections and the referendum, it turned out he hadn't voted, saying 'Will any of it stop all of this?' (2017b, p. S273), expressing his sense of hopelessness.

Interactions like the ones above are for me situations, meaning specifically they are scenarios located in place and time within which specific relations play themselves out - in this case class relations and relations of private property. Individuals in these situations are particular selves with their own unique biography and personal experiences, yet because of the alienated nature of their relationships they appear only as representatives of a kind, type, or role. This then involves misrecognition; which is to say, people seeing each other only as a type and not the person - the real living individual - within it. The emotions that are generated in these situations are part of this, in that they reflect the relations between kinds and not that between selves or persons. If the people met in other circumstances where they could get to know one another as persons, they may find they had much more in common. However, in situations like the ones above, 
in the play of alienated relations, that is not possible. This is because these situations are the scenes of wider class and property relations.

These wider class relations are also evident in people's relationships to authorities, institutions, and government, something that was seen in 2017 with the Grenfell Tower fire disaster in North Kensington, West London. The fire broke out in a high-rise block of flats in the early morning of $14^{\text {th }}$ June and up to this point in time it is thought 72 people died. Grenfell Tower was built as council housing and mainly housed working class residents, many of them from different ethnic minorities, with a small number of flats being privately owned and occupied or leased out for private rent. However, most flats were owned and rented by the local council (the Royal Borough of Kensington and Chelsea) with the tower block being managed by a Tenant Management Organisation (TMO) made up of residents, council-appointed members, and independent members. This particular Borough of London is one of the richest in Britain with Grenfell Tower being surrounded by more affluent neighbourhoods. After the fire it became clear from reports in the media that local residents had long complained about safety fears inside the block of flats, with a tenants' action group having been formed, feeling that the council and their appointees on the TMO were not listening to their concerns. Many residents felt the local authority wanted them out of the Borough so the land could be sold to build more expensive housing, something that was reflected after the fire when many residents who had lost their homes insisted they be temporarily rehoused in the Borough so the council could not use this as an opportunity to move them out of the area. 
A few examples from the media give an indication of the feelings and emotions of local residents who had been affected by the fire in its immediate aftermath. A report from the day of the fire talks of the grief and frustration of those looking for loved ones or desperately searching for news of them, while others were looking for a place to stay. There was also anger and frustration that there was no relief effort from local or national government, which seemed entirely absent, and in its place local charities, such as Islamic Relief, their workers and volunteers, were providing aid. With no official lines of communication the charities were communicating through WhatsApp and local people were bringing supplies - such as food, water and clothing - for the victims of the fire (The Guardian, 2017a). In a video posted the following day by a national newspaper, people express their pride in their fellow local residents who pulled together to help out, with one man saying, 'People care for each other, its beautiful to see'. Another resident praised the young people of the area and their efforts to help, bringing food and other items. However, one women voiced her anger at the authorities, in that 'A building like that wouldn't be built in a rich area. Because everyone who lives here is poor and working class, that's why it happened' (The Guardian, 2017b).

Amidst the pride, solidarity, grief and mourning, a sense of anger and injustice was clearly aimed at all authorities. On the evening after the fire a group of men tried to protect a distraught woman when a journalist moved in to film her, causing a clash with police involving shouting and screaming (The Guardian, 2017a). The following day when the Queen came to visit the scene and meet with local residents, a journalist recorded the following incident: 
One man shouted furiously at her [the Queen's] departing car, holding a photo of two babies he said were family members. He said they were "left to die in that tower", adding: "Where was the Queen before this? Where was the government? Where was the media? You only come now! Left to die here by all of you, and the police, and firefighters."

"Not the police and firefighters," another local said. "OK, not them," he said (The Guardian, 2017c).

Protestors also organised a march through central London that passed Downing Street, chanting 'No justice, no peace'. In Kensington hundreds of people tried to force their way into the Town Hall, demanding that local councillors come out of their offices to answer questions. Specifically, they wanted assurances that local people who had lost their homes in the fire would be rehoused in the area and not moved out. The Prime Minster also needed police protection as she came to the area to meet with local residents. On leaving the meeting 'an angry crowd of locals booed her and told her forcefully that she was not welcome there' (The Guardian, 2017d).

A number of things emerge from this important for my analysis of alienation. First, it is important to note that the residents living in and around the Grenfell Tower area are not totally powerless or alienated, as they draw huge strength and resilience from local relationships with friends and neighbours, in which 
there is clearly mutual respect and recognition. They are not simply isolated individuals who appear divorced from some generalised social whole, but have solidarity and resources from those close to them. From interviews in the newspapers and on television they are articulate and sure of themselves. And yet they are clearly alienated from authorities who, they feel, haven't listened to them, do not represent them, and indeed are actively hostile to them in that they do not want them living in the area. In the aftermath of the fire both local and national government effectively abandoned them and left them to manage by their own resources. Their anger, despair, grief and loss all speak to their alienation from authority and the situation this has created: and it is only in that situation that their feelings and emotions take on sense and meaning.

\section{Discussion}

What I have been arguing here is that alienation does not only create a situation where people feel divorced from their feelings and emotions. Indeed in many respects the opposite is the case, in that feelings and emotions, along with people's practical reasoning about their situation, tells them a great deal about the alienated aspects of their social relations. Feelings, emotions, and practical reasoning reflect the increasingly unequal and unfair nature of social relations in neoliberal, globalised capitalist relations, where conventional politics and political parties that are meant to represent different sections of the population, have in effect abandoned the poorer strata of society and the working class in order to bail out failed financial institutions and deregulate markets to facilitate 
capital accumulation. Those left out of economic growth and the political calculations of parties attempting to win over key voters, feel abandoned and estranged from authorities and institutions to which they have a vital relationship as citizens, such as political parities, local, national and international governments, and the media. There is also a structure of feeling among many working class communities that once took pride in skilled, relatively well-paid work, which involves the loss of status in the eyes of others and in their own sense of self-respect, as the basis of their standing in society - decent work, community identity and solidarity, and strong family ties - are undermined or threatened. The result is anger at authorities and established centres of political power and feelings of sadness and fear about what has been lost and what is still under threat.

I think Ollman (1971) is wrong, therefore, when he says that in alienated relations people 'cannot respond either emotionally or intellectually in the manner which takes their objective conditions fully into account' (p. 238). On the contrary, my analysis here suggests that in alienated relations people can respond both emotionally and intellectually in a way that takes their objective conditions into account. I also think it is wrong to claim, as many commentators do, that contemporary politics runs purely on emotions like anger, fear, and loss, and that this has distorted or biased people's rational, cognitive grasp of objective reality. The participants in the studies above and the victims of the Grenfell Tower fire can speak eloquently and rationally about their emotions and of the objective social conditions that make them feel the way they do. Perhaps the key word in what Ollman says above, however, is about people not being able 
to fully take their objective conditions into account. Alienated relations do create distortions in some aspects of the way people think and feel, especially towards others of their own class who take on roles, like the security guards, that have them protecting private property for a wage. Many of the white working class participants in Mckenzie's research also felt that their problems in getting school places for their children and good housing in the areas they wanted to live, along with more secure well-paid work, were exacerbated not only by austerity cuts to services but also by immigration. Yet my brief study here of newspaper reports of the responses of victims of the Grenfell Tower fire disaster, shows that they too - many of them from ethnic minorities and some who were migrants suffered the same problems as those from the white working class: abandonment by authorities and a sense of estrangement from political power and influence. The fear of immigration that centres on how it might threaten to undercut already depressed wages, or put more pressure on local services already at breaking point from austerity spending cuts, is exploited by right wing media and politicians, creating another way in which people whose interests are very much the same can be divided and alienated from one another.

What does this mean, though, for the fractious and deeply emotional state of contemporary society and politics? Mouffe (2005) has argued that democratic politics must be able to mobilise passions towards democratic designs and 'needs to have a real purchase on people's desires and fantasies' (p. 6). The liberal desire to move beyond left and right to reach a state of the post-political is bound to fail, as politics must have a partisan character. However, I disagree with Mouffe's Foucaultian/Nietzschean take on this, and her drawing on the ideas of 
the political theorist Carl Schmitt, arguing that partisanship is necessary because politics rests on a recurring 'agonism'. For me, it is the class divided nature of capitalist society, as uncovered in the research I've drawn upon here, which requires that people's feeling and thinking is reflected in, and modified by, partisan democratic politics and debate. But it is not just a return to partisan politics that is necessary. If my analysis is correct and particular social classes are experiencing estrangement from democratic institutions that often stand against them as a hostile power, then we need to create institutions that can overcome this form of alienation. Such institutions would have to be ones with which people could identify and make appropriation of the human heritage possible - not simply the appropriation of capacities through work, but creating capacities through participation in civic and political institutions through which people can become part of the ethical life of society (Jaeggi, 2014).

For Marx (1977), to abolish alienation a society would also have to abolish private property and capitalist social relations. If this seems too idealistic, then it is important to say that this would not necessarily mean the abolition of all tension and disagreement between people, or of misrecognition and failure to communicate: it would mean the elimination of the kinds of estrangement and class distortions, both within and between social classes, that I have been focusing on here. According to Heller (2009), Marx 'confronted the reduced, abstracted, impoverished life of feeling in alienated society with the qualitative wealth of feelings of man active in many directions and involved in many directions' (p. 208). Instead of scrambling to make a living in deregulated labour markets and under conditions of austerity, if people were more actively involved 
in political and civic institutions and also had the necessary resources at their disposal, the kind of solidarity, fellow-feeling, and spontaneous giving evident in the aftermath of the Grenfell Tower fire may be more common across the whole of society, not only in times of disaster.

\section{Conclusion}

In this article I have focused on the alienation between people, and between people and institutions, which is considered to be a deficient or broken relationship - the realm of estrangement. In capitalism, just as producers give up the value of their labour power and lose ownership of what they produce, they also feel to lose ownership of the political institutions they jointly create, recreate, and legitimise - if only passively - as citizens. Indeed, if the relation between people and political institutions becomes too estranged, these institutions take on the quality of quasi-supreme entities that demand obedience from, and act to discipline, those who have created and sustain them. People come to feel abandoned by key social institutions that can, in turn, become actively hostile to sections of the population. In these estranged relations people feel anger and dissatisfaction towards institutions, perhaps even to processes of democratic politics, and also feel sadness and loss at the threat to their own families and communities that such abandonment results in. There is also a structure of feeling in which people perceive the loss of their own social status in the eyes of others, as their social position diminishes through the lack of skilled, well-paid, and secure employment, and also through the loss of self-pride 
expressed in neighbourhoods and communities becoming increasingly impoverished and lacking cohesion and solidarity of identity. The way people come to see their own self is through the distortions of alienated, deficient relationships. As social beings, for humans the condition of interdependence is universal and has to be reflected in social institutions in which people can participate and with which they identify. In the end that is the only answer to the particular forms of estrangement that alienation creates, and to the feelings of anger, frustration, sadness and loss that seem so deeply entrenched in the abandoned sections of modern forms of emotional capitalism.

\section{References}

Bakhtin, M. M. (1984) Problems of Dostoevsky's poetics (ed \& trans C. Emerson), Minneapolis, MN: University of Minnesota Press.

Brewer, T. (2011) 'On alienated emotions', in C. Bagnoli (ed), Morality and the emotions, Oxford, UK: Oxford University Press. pp. 276-299.

Burkitt, I. (2014) Emotions and Social Relations, London, UK: Sage.

Emirbayer, M. (1997) 'Manifesto for a relational sociology', American Journal of Sociology, 103: 281-317. doi: 10.1086/231209

The Guardian (2017a) Locals' anger and frustration spills out after Grenfell Tower fire, https://www.theguardian.com/uk-news/2017/jun/14/grenfell-fire$\underline{\text { location-reaction-anger }}$ 
The Guardian (2017b) Grenfell Tower fire is corporate manslaughter, says Labour MP, https://www.theguardian.com/uk-news/2017/jun/15/grenfell-towerdeath-toll-rises-to-17-as-hope-to-find-survivors-wanes

The Guardian (2017c) Protesters march as anger mounts over Grenfell Tower response - as it happened, https://www.theguardian.com/uknews/live/2017/jun/16/grenfell-tow...-tragedy-latestupdates?page=with:block-5943cfe2e4b0240ef761514f

The Guardian (2017d) 'We want justice': Grenfell Tower protests spill onto the streets, https://www.theguardian.com/uk-news/2017/jun/16/we-want-justicegrenfell-tower-protest-spills-into-town-hall

Heller, A. (2009) A theory offeelings (2 ${ }^{\text {nd }}$ ed. Trans. M. D. Fenyö), Lanham, MD: Lexington Books. (Original work published 1979).

Hochschild, A. R. (1983) The managed heart: Commercialization of human feeling, Berkeley, CA: University of California Press.

Holmes, M. \& Manning, N. (2013) “'Them that runs the country don’t know what they're doing": Political dissatisfaction amongst members of the white working class', The Sociological Review, 61: 479-498. doi: 10.1111/1467-954X.12033

Holmes, M. \& McKenzie, J. (2018) 'Relational happiness through recognition and redistribution: Emotion and inequality', European Journal of Social Theory, doi: $10.1177 / 1368431018799257$

Illouz, E. (2007) Cold intimacies: The making of emotional capitalism, Cambridge, 
UK: Polity Press.

Jaeggi, R. (2014) Alienation (trans F. Neuhouser \& A. E. Smith), New York, NY:

Columbia University Press.

Mair, P. (2013) Ruling the void: The hollowing of Western democracy, London, UK: Verso.

Manning, N. \& Holmes, M. (2013) “"He's snooty 'im”: Exploring "white working class" political disengagement', Citizenship Studies, 17: 479-490. doi:

$10.1080 / 13621025.2013 .793082$

Marx, K. (1977) 'Economic and philosophical manuscripts', in D. McLellan (ed), Karl Marx: Selected writings, Oxford, UK: Oxford University Press. pp. 75-112. (Original work published 1844).

Mckenzie, L. (2017a) “It's not ideal”: Reconsidering "anger" and "apathy" in the Brexit vote among an invisible working class', Competition \& Change, 21: 199210. doi: $10.1177 / 1024529417704134$

Mckenzie, L. (2017b) 'The class politics of prejudice: Brexit and the land of nohope and glory', British Journal of Sociology, 68(S1): S265-S280. doi: $10.1111 / 1468-4446.12329$

Mead, G. H. (1934) Mind, self, and society from the standpoint of a social behaviourist (ed C. W. Morris), Chicago, IL: Chicago University Press.

Mouffe, C. (2005) On the political, London, UK: Routledge. 
Ollman, B. (1971) Alienation: Marx's conception of man in capitalist society, Cambridge, UK: Cambridge University Press.

Sève, L. (1978) Man in Marxist theory and the psychology of personality (trans. J. McGreal), Sussex, UK: Harvester.

Szanto, T. (2017) 'Emotional self-alienation', Midwest Studies in Philosophy, XLI: 260-286. doi: 10.1111/misp12074

Thompson, E. P. (1980) The making of the English working class, London, UK: Penguin. (Original work published 1963). 